\title{
The Impact of Copper Tetramine Hydroxide Treatments on Wheat Yield
}

\author{
R. SCHMIDT, M. BARKÓCZY, P. SZAKÁL and R. KALOCSAI \\ University of West Hungary, Faculty of Agricultural and Food Sciences, \\ Mosonmagyaróvár (Hungary)
}

\begin{abstract}
Although much research has been carried out related to the role of trace elements in plant nutrition a lot of facts are still to be discovered. Intensive crop production and the partial replacement of nutrients often lead to nutrient imbalances and deficiencies (CSATHÓ, 1994). Nutritional anomalies frequently result in reduced yield and poor product quality. Many interactions occurring among nutrients make the question even more complex. That is the reason why the cycling and replacement requirements for the three major nutrients $(\mathrm{N}, \mathrm{P}, \mathrm{K})$ are estimated with more or less accuracy (KÁDÁR, 1987). This estimation is more difficult in the case of trace elements where the number of interactions in plant and soil is much larger. According to national and FAO studies the available copper content of Hungarian soils is low on a considerable proportion of the arable land (SILlANPÄÄ, 1982; FeKETE \& PATÓCS, 1988).

Copper, among other metal ions, plays an important role in the regulation and promotion of essential biochemical reactions taking place in plant cells. Copper requirement is especially expressed in the case of cereals (KUDUK, 1988; SZAKÁL, 1987). In lack of copper the protein synthesis, the N uptake of cereals is hindered (KÁDÁR \& SHALABY, 1984, 1985; SZAKÁL \& BARKÓCZY, 1988; ERCAN \& VELIOGLU, 1990). The missing trace elements can be replaced through the soil or by foliar application. Although trace elements given through the soil contribute to problem solving in a more basic way, in many cases foliar application offers the only possibility for eliminating the deficiencies (SZAKÁL, 1987). GRAHAM (1976) - applying copper sulphate for copper fertilization of wheat in the form of soil and foliar treatments - experienced that foliar fertilization performed better. The best application time was at the tillering phenological phase, which was applied in our experiments too.
\end{abstract}

Correspondence to: Dr. Rezső SCMIDT, University of West Hungary, Faculty of Agricultural and Food Sciences, Department of Soil Management, H-9200 Mosonmagyaróvár, Vár u. 2. Hungary. E-mail: schmidtr@mtk.nyme.hu 


\section{Material and Methods}

Three years' experimental results are reported in present publication about the effect of copper tetramine hydroxide complex on the yield of winter wheat cultivar Mv-14. The copper tetramine hydroxide was prepared from microelectronical copper waste as a secondary raw material plant nutrient (SZAKÁL \& SCHMIDT, 1996; SCHMIDT et al., 2000).

The experiment was set up in randomized block design with four replications. The size of the experimental plots was $10 \mathrm{~m}^{2}$ in 1991,1992 , and $12.5 \mathrm{~m}^{2}$ in 1988. The experiment was carried out at the experimental site of the University of West Hungary on Danube alluvial soil in 1988 and 1992 and on peat soil in 1991. Soil samples were collected from each plot before starting the experiment. The soil could be considered homogeneous, so average soil nutrient contents are presented in Table 1 . Wheat seeds were sown with a Wintersteiger plot drill and yields were harvested with a Wintersteiger plot harvester.

Treatments were applied at two phenological phases: at the end of tillering and at flowering with $0.1 ; 0.3 ; 0.5 ; 1.0$ and $2.0 \mathrm{~kg} \mathrm{ha}^{-1}$ copper doses respectively. Present publication evaluates the results of the treatments carried out at the tillering phenological phase. Spraying was done with 0.6 liter $10 \mathrm{~m}^{-2}$ water solution of copper amine complex, prepared according to SCHMIDT et al. (2000). The control plots were treated with the respective amount of $\mathrm{N}$ contained by the copper amine complex in the form of $\mathrm{NH}_{4} \mathrm{NO}_{3}$ solution. A water sprayed control was also applied. As no significant difference was found between the results measured in the water and $\mathrm{N}$ controls, these plots were treated uniformly as controls afterwards.

The results were evaluated by ANOVA and regression analysis.

Table 1

The nutrient content of the experimental soils

\begin{tabular}{|l|c|c|c|}
\hline Parameter & $\begin{array}{c}\text { Danube alluvial } \\
\text { Fluvisol } \\
1988\end{array}$ & $\begin{array}{c}\text { Peat } \\
\text { Histosol } \\
1991\end{array}$ & $\begin{array}{c}\text { Danube alluvial } \\
\text { Fluvisol } \\
1992\end{array}$ \\
\hline $\mathrm{pH}(\mathrm{KCl})$ & 7.6 & 6.9 & 7.3 \\
$\mathrm{~K}_{\mathrm{A}}$ & 41.0 & 43.0 & 43.0 \\
$\mathrm{CaCO}_{3} \%$ & 16.0 & 3.4 & 12.5 \\
$\mathrm{Humus} \%$ & 2.6 & 3.5 & 3.2 \\
$\mathrm{ALP}_{2} \mathrm{O}_{5} \mathrm{mg} \mathrm{kg}^{-1}$ & 285.0 & 282.0 & 291.0 \\
$\mathrm{AL}-\mathrm{K}_{2} \mathrm{O} \mathrm{mg} \mathrm{kg}$ & 230.0 & 226.0 \\
$\mathrm{AL}-\mathrm{Mg} \mathrm{mg} \mathrm{kg}$ & 215.0 & 209.0 & 257.0 \\
$\mathrm{AL}-\mathrm{Na} \mathrm{mg} \mathrm{kg}{ }^{-1}$ & 282.0 & 53.0 & 61.0 \\
EDTA-Zn mg kg$^{-1}$ & 84.0 & 2.3 & 3.7 \\
EDTA-Cu mg kg & 4.3 & 2.5 & 3.4 \\
\hline
\end{tabular}

$\mathrm{K}_{\mathrm{A}}=$ Upper limit of plasticity according to Arany; $\mathrm{AL}=$ ammonium lactate extraction 


\section{Results and Discussion}

\section{Winter wheat yield}

Due to the copper treatments the yield increases (Table 2) and the increase is significant at the $5 \%$ probability level (Table 3 ). The $2 \mathrm{~kg} \mathrm{ha}^{-1}$ copper dose had a slight depressive effect and the yield decreased in all three experimental years. The coefficient of variation is slightly high, which shows the effect of environmental factors having a strong influence on yield components and yield. The treatments influenced the yield in the same way in all experimental years that is underlined by the fact that the "Treatment $x$ Year" relationship is not significant (Table 3).

Table 2

The yield of winter wheat $\left(\mathrm{kg} \mathrm{m}^{-2}\right)$ in the copper treatments

\begin{tabular}{|l|c|c|c|c|c|}
\hline $\begin{array}{l}\text { Treatment } \\
\mathrm{Cu} \mathrm{kg} \mathrm{ha}\end{array}$ & 1988 & 1991 & 1992 & Average & CV\% \\
\hline 0 & 0.75 & 0.52 & 0.62 & 0.63 & 18.31 \\
0.1 & 0.76 & 0.55 & 0.62 & 0.64 & 16.62 \\
0.3 & 0.78 & 0.59 & 0.60 & 0.66 & 16.28 \\
0.5 & 0.81 & 0.60 & 0.63 & 0.68 & 16.70 \\
1 & 0.82 & 0.61 & 0.64 & 0.69 & 16.46 \\
2 & 0.73 & 0.57 & 0.61 & 0.64 & 13.08 \\
$\mathrm{LSD}_{5 \%}$ & 0.092 & 0.035 & 0.047 & 0.04 & \\
\hline
\end{tabular}

Table 3

Table of variance (Yield)

\begin{tabular}{|l|c|c|c|c|c|}
\hline Source & $\mathrm{SQ}$ & $\mathrm{dF}$ & $\begin{array}{c}\text { Mean } \\
\text { squares }\end{array}$ & $\mathrm{F}$ & Sign \\
\hline Total & 0.1466 & 17 & & & \\
Year & 0.1337 & 2 & & & \\
Treatment & 0.0088 & 5 & 0.0018 & 4.35 & $*$ \\
Treatment x year & 0.0041 & 10 & 0.0004 & 0.93 & NS \\
Error & - & 45 & 0.0004 & & \\
\hline
\end{tabular}

A regression analysis was carried out to determine the relationship between copper doses and yield. The changes in yield due to the application of copper can be described by a quadratic equation that is significant at $5 \%$ probability level (Figure 1). The curve also displays that the $2 \mathrm{~kg} \mathrm{ha}^{-1}$ copper dose already had a yield reducing effect. The calculated maximum of the curve is at $1.04 \mathrm{~kg}$ ha $^{-1}$ copper dose with $0.692 \mathrm{~kg} \mathrm{~m}^{-1}$ yield. 


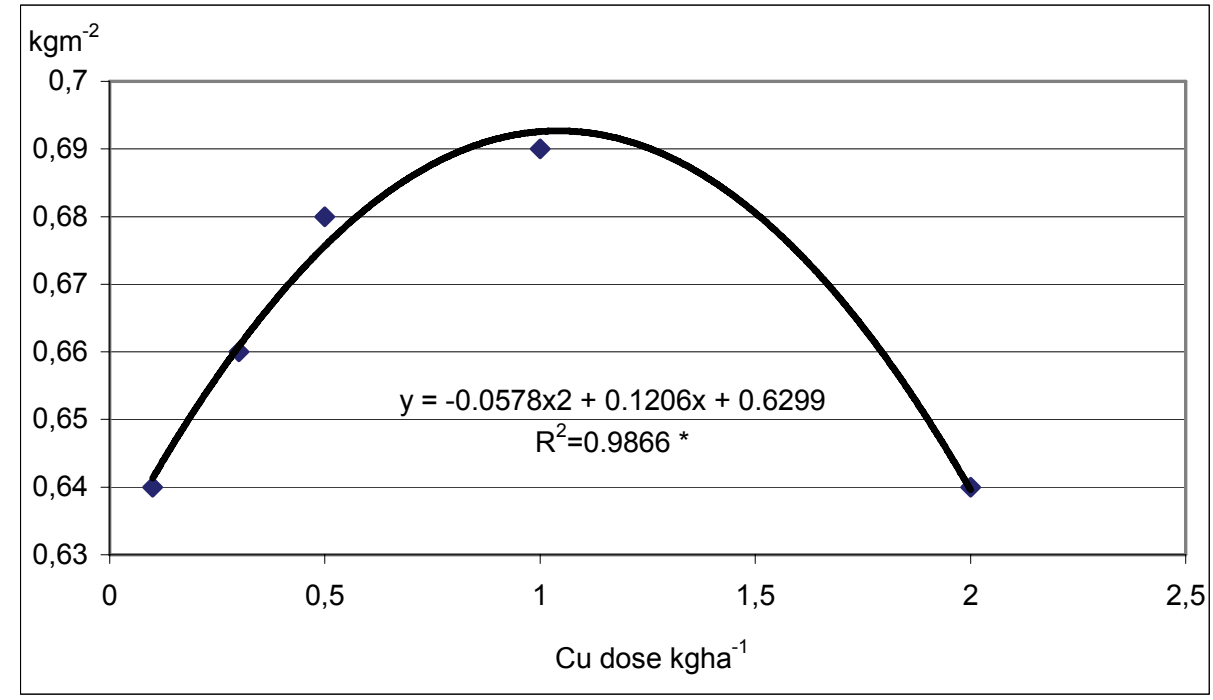

Figure 1

The relationship between the yield of winter wheat and the copper doses, three years' average

\section{Kernel weight}

Kernel weight also increases due to the application of the copper complex (Table 4). It seems to be a general rule that the $2 \mathrm{~kg} \mathrm{ha}^{-1}$ copper dose has a slightly depressive effect and decreases kernel weight, too. In terms of this parameter, it can also be established that there is a marked variation between the experimental years. The variation of coefficient values (CV\%) shows a balanced effect with the exception of the $2 \mathrm{~kg} \mathrm{ha}^{-1}$ copper dose. That is why we carried out the analysis of variance by both including and omitting the $2 \mathrm{~kg} \mathrm{ha}^{-1}$ copper dose. The differences can be seen in Tables 5 and 6 , indicating that when the $2 \mathrm{~kg} \mathrm{ha}^{-1}$ treatment is included the effect is non-significant, but a sig-

Table 4

The 1000 kernel weight of winter wheat $(\mathrm{g})$ in the copper treatments

\begin{tabular}{|l|r|r|r|r|r|}
\hline $\begin{array}{l}\text { Treatment } \\
\mathrm{Cu} \mathrm{kg} \mathrm{ha}\end{array}$ & 1988 & 1991 & 1992 & Average & CV\% \\
\hline 0 & 33.00 & 37.46 & 43.20 & 37.89 & 13.50 \\
0.1 & 33.08 & 37.88 & 43.93 & 38.30 & 14.20 \\
0.3 & 34.00 & 37.37 & 44.28 & 38.55 & 13.59 \\
0.5 & 34.30 & 38.00 & 44.30 & 38.87 & 13.01 \\
1 & 34.40 & 37.95 & 44.30 & 38.88 & 12.90 \\
2 & 29.20 & 36.75 & 43.75 & 36.57 & 19.90 \\
LSD $_{5 \%}$ & 1.09 & 1.04 & 1.23 & 1.87 & \\
\hline
\end{tabular}


nificant difference was proven in the "Treatment $x$ Year" interaction. When the evaluation is carried out without the $2 \mathrm{~kg} \mathrm{ha}^{-1}$ copper dose the "Treatment $\mathrm{x}$ Year" interaction is not significant but there is an effect proven at 5\% probability level regarding the treatments.

Table 5

Table of variance of the kernel weight ( $2 \mathrm{~kg} \mathrm{ha}^{-1}$ copper dose included)

\begin{tabular}{|l|r|r|c|c|c|}
\hline \multicolumn{1}{|c|}{ Source } & \multicolumn{1}{c|}{ SQ } & dF & Mean square & F & Sign. \\
\hline Total & 385.0988 & 17 & & & \\
Year & 363.8964 & 2 & & & \\
Treatment & 11.4163 & 5 & 2.2833 & 2.33 & NS \\
Treatment x year & 9.7861 & 10 & 0.9786 & 7.04 & $* * *$ \\
Error & - & 45 & 0.1390 & & \\
\hline
\end{tabular}

Table 6

Table of variance of the kernel weight ( $2 \mathrm{~kg} \mathrm{ha}^{-1}$ copper dose not included)

\begin{tabular}{|l|r|r|c|c|c|}
\hline \multicolumn{1}{|c|}{ Source } & \multicolumn{1}{c|}{ SQ } & dF & Mean square & F & Sign. \\
\hline Total & 269.8849 & 14 & & & \\
Year & 266.8367 & 2 & & & \\
Treatment & 2.1041 & 4 & 0.5260 & 4.46 & $*$ \\
Treatment x year & 0.9442 & 8 & 0.1180 & 0.85 & NS \\
Error & - & 45 & 0.1390 & & \\
\hline
\end{tabular}

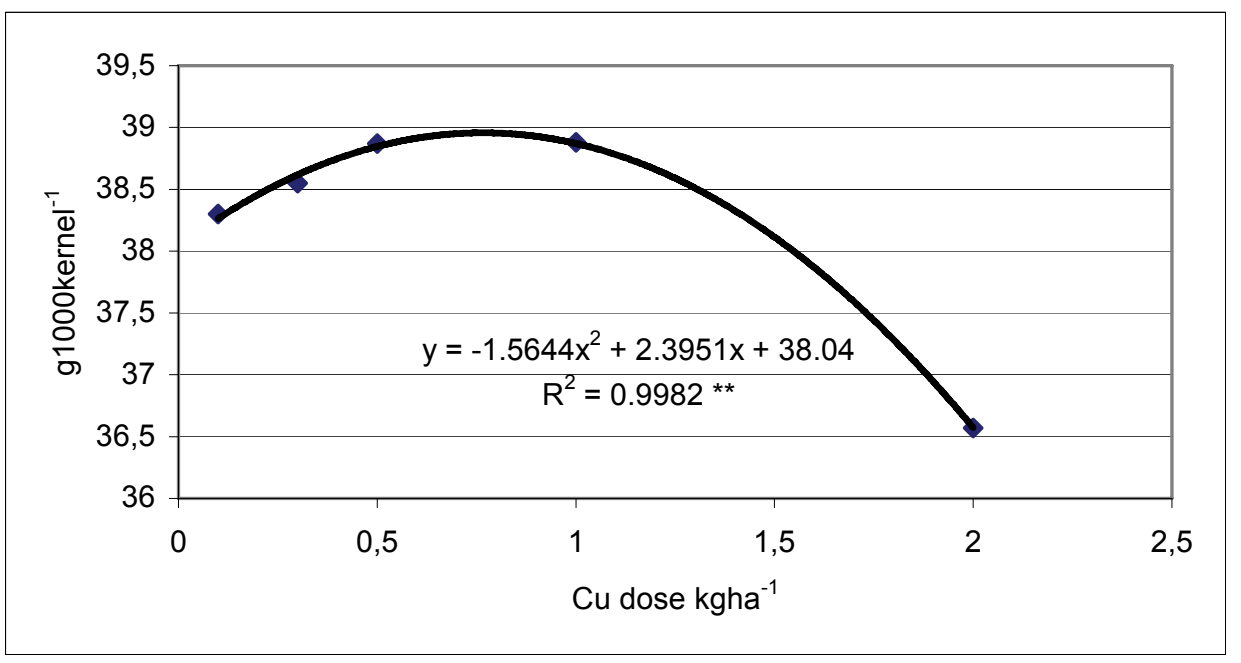

Figure 2

The relationship between kernel weight and copper treatments, three years' average (the $2 \mathrm{~kg} \mathrm{ha}^{-1}$ copper dose included) 
A regression analysis was also made to examine the relationship between copper application and the changes in the 1000 kernel weight (Figures 2 and 3). The curves look a bit different, depending on the inclusion or exclusion of the 2 $\mathrm{kg} \mathrm{ha}^{-1}$ copper dose. In spite of the different appearance of the curves the calculated values are almost the same. The calculated maximum is at the $0.77 \mathrm{~kg}$ $\mathrm{ha}^{-1}$ (Figure 2) and at the $0.79 \mathrm{~kg} \mathrm{ha}^{-1}$ (Figure 3) copper dose, respectively. There is practically no difference in the calculated maximum 1000 kernel weight values: $38.95 \mathrm{~g}$ (Figure 2) and $38.947 \mathrm{~g}$ (Figure 3), respectively.

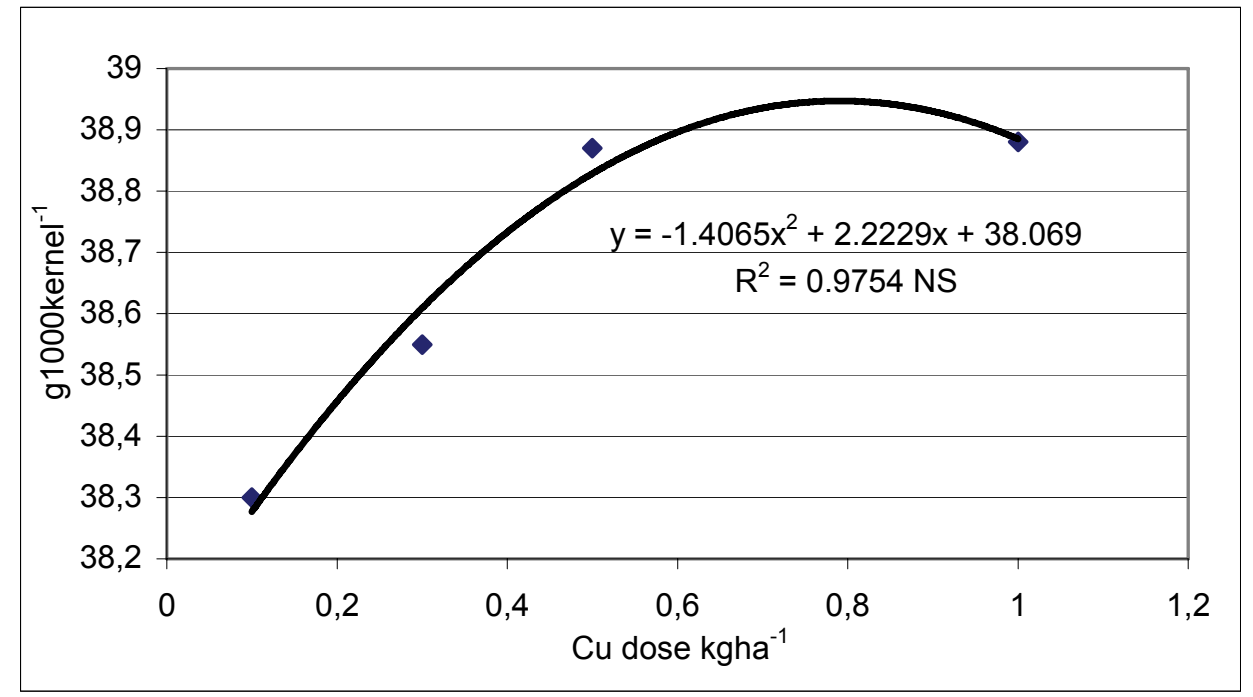

Figure 3

The relationship between kernel weight and copper treatments, three years' average (the $2 \mathrm{kgha}^{-1}$ copper dose not included)

\section{Raw protein}

The application of copper markedly increased the raw protein content of winter wheat (Table 7). The effect is significant at the $0.1 \%$ probability level (Table 8). Due to environmental factors the raw protein content varies according to years, but the CV values still indicate a quite balanced effect. The $2 \mathrm{~kg}$ $\mathrm{ha}^{-1}$ copper dose, in a variable extent, but decreased the raw protein content of wheat.

The relationship between copper doses and the raw protein content of wheat can be described by a quadratic regression curve (Figure 4). The calculated maximum of the regression curve is at the $1.12 \mathrm{~kg} \mathrm{ha}^{-1}$ copper dose and equals $13.28 \%$ raw protein content. 
Table 7

The raw protein content of winter wheat (\%) due to the copper treatments

\begin{tabular}{|l|r|r|r|r|r|}
\hline $\begin{array}{c}\text { Treatment } \\
\mathrm{Cu} \mathrm{kg} \mathrm{ha}\end{array}$ & 1988 & 1991 & 1992 & Average & CV\% \\
\hline 0 & 13.20 & 11.00 & 12.85 & 12.35 & 9.57 \\
0.1 & 13.43 & 11.20 & 12.95 & 12.53 & 9.37 \\
0.3 & 13.60 & 11.35 & 13.53 & 12.83 & 9.97 \\
0.5 & 13.93 & 11.60 & 13.58 & 13.04 & 9.64 \\
1 & 14.13 & 11.90 & 13.73 & 13.25 & 8.97 \\
2 & 13.49 & 11.18 & 13.58 & 12.75 & 10.67 \\
LSD $_{5 \%}$ & 0.65 & 0.54 & 0.4 & 0.25 & \\
\hline
\end{tabular}

Table 8

Table of variance of the raw protein content

\begin{tabular}{|l|r|r|c|c|c|}
\hline \multicolumn{1}{|c|}{ Source } & \multicolumn{1}{c|}{ SQ } & dF & Mean square & F & Sign. \\
\hline Total & 20,1337 & 17 & 17 & & \\
Year & 18,3220 & 2 & 2 & & \\
Treatment & 1,6242 & 5 & 5 & 17,33 & $* * *$ \\
Treatment x year & 0,1875 & 10 & 10 & 0,58 & NS \\
Error & - & 45 & 45 & & \\
\hline
\end{tabular}

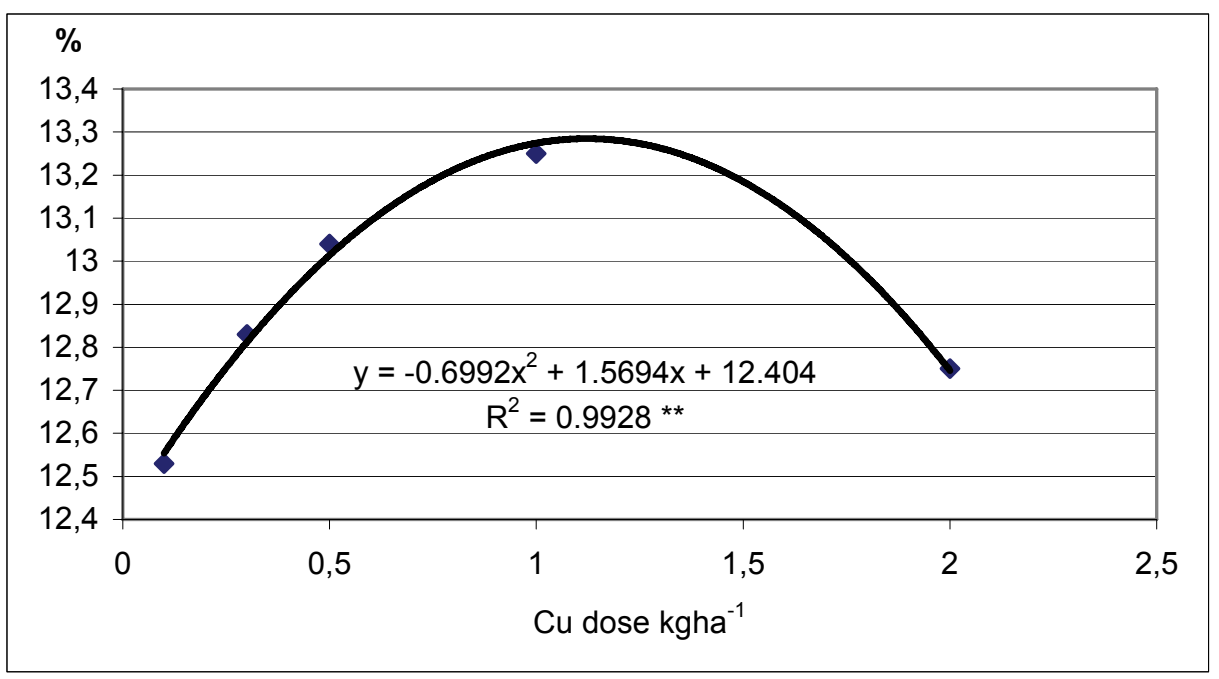

Figure 4

The relationship between the raw protein content of winter wheat and copper treatments, three years' average 


\section{Summary}

Authors studied the effect of copper nutrition on the yield, kernel weight and raw protein content of winter wheat. Copper was applied in the form of copper tetramine hydroxide that was produced from a clean copper containing waste originating from microelectronical industry. After suitable chemical transformation this waste can be used as an excellent secondary raw material for the preparation of copper fertilizer. The foliar application of copper tetramine hydroxide complex at the phenological phase of tillering significantly increased the yield, kernel weight and raw protein content of winter wheat. The calculated copper doses that gave the maximum yield, raw protein content and kernel weight were $1.04,1.12$ and $0.77 \mathrm{~kg} \mathrm{ha}^{-1}$ respectively.

Key words: winter wheat, copper, yield, kernel weight, raw protein content

\section{References}

CsATHÓ, P., 1994. Heavy metals and other toxic elements in the soil-plant system. (In Hungarian) Agrokémia és Talajtan. 43. 371-398.

ERCAN, R. \& VeliIOGLU, S., 1990. Mineral composition of main wheat cultivars and their flour. Doga,-Turk-Tarim-ve-Ormancilik-Dergisi. 14. (4) 393-400.

FeKeTE, A. \& PATÓCS, I., 1988. Microelement fertilization depending on essential element contents of Hungarian soils. (In Hungarian) Hungarochem. Keszthely. 393400.

GraHAM, R. D., 1976. Physiological aspects of time of application of copper to wheat plants. J. Experimental Botany. 271. 713-724.

KÁDÁR, I., 1987. Mineral nutrient turnover of agriculture in Hungary. (In Hungarian) Növénytermelés. 36. (6) 517-526.

KÁDÁR, I. \& ShalabY, M. H., 1984. Correlations between $\mathrm{N}$ and Cu fertilization in calcareous sandy soil. (In Hungarian) Agrokémia és Talajtan. 33. 268-274.

KÁDÁR, I. \& SHALABY, M., 1985. Effect of $\mathrm{N}$ and Cu fertilization on element content of soil and plant. (In Hungarian) Növénytermelés. 34. (2) 119-127.

KUDUK, C., 1988. Influence of liming with addition of copper on the initial growth of wheat. Zeszyty Naukowe Akadémii Rolniczej we Wroclawiu. 47. 169-177.

SCHMIDT, R. et al., 2000. Transformation of copper and zinc containing residues into potential trace element nutrients of plants. In: Analytical and Environmental Conference. 114-119. Univ. West Hungary, Fac. Agriculture. Mosonmagyaróvár.

SILlanpäÄ, M., 1982. Micronutrients and the Nutrient Status of Soils. A Global Study. FAO Soils Bulletin 48. Rome.

SZAKÁL, P., 1987. Experiments for the agricultural use of copper containing wastes. (In Hungarian). VIII. Gépipari Környezetvédelmi Napok, Gyõr. 404-414.

SZAKÁL, P. \& BARKÓCZY, M., 1988. Application of copper tetramine hydroxid complex for increasing yield and gluten content of winter wheat (In Hungarian) Hungarochem. Keszthely. 23-31.

SZAKÁL, P. \& SCHMIDT, R., 1996. Effect of copper-amine-complex produced from waste on the yield and bread-making quality of wheat. In: Recycling of Plant Nutrients from Industrial Processes. Braunschweig, 263-271. 